\title{
lleostomy Site
}

National Cancer Institute

\section{Source}

National Cancer Institute. Ileostomy Site. NCI Thesaurus. Code C122642.

A surgically created external opening into the ileum. 